\title{
“IT'S EXHAUSTING TO CREATE AN EVENT OUT OF NOTHING": Slow Violence and the Manipulation of Time
}

\author{
CHLOE AHMANN \\ George Washington University \\ (D) http:// orcid.org/0000-0002-8974-190X
}

On December 15, 2015, nearly two hundred people marched outside the offices of the Maryland Department of Environment (MDE), urging state officials to "pull the permits" for the Fairfield Renewable Energy Project. The Project, a euphemistic name for the four-thousand-ton-per-day trash incinerator slated for construction in Baltimore's industrial hinterlands, had been permitted to release thousands of pounds of lead, mercury, and fine particulate matter into Curtis Bay, already Maryland's most polluted neighborhood. ${ }^{1}$ After years of debate, dozens of meetings, and hundreds of petitions were met with silence from the state, protestors had gathered to chide the agency for its inaction. Locked outside the building, they chanted in unison: "We're holding our breath."

Nearby, Baltimore City police idled on an unexpectedly ordinary evening, with jurors deadlocked in the first of the Freddie Gray trials and citizens awaiting their decision too quietly. (Gray's death from injuries sustained while in police custody had sparked citywide protests earlier that year.) Commotion at MDE drew the officers' attention. Within hours, they had arrested seven protesters for civil disobedience and summoned four armored vans to the scene. As sixty-odd officers urged back the peaceful crowds, who marveled at the state's now swift and decisive response, one young black man standing beside me broke the refrain. 
Elijah, a high school student in Curtis Bay, pushed to the front of the group and locked eyes with an officer sitting in the vehicle in which his classmates were restrained. Then, he transformed the exasperated "we're holding our breath" into the asthmatic "we can't breathe." 2 This essay addresses how gradual, often imperceptible conditions of distress can lead not to the incapacitation of victims, but to deliberate and creative formulations of urgency like his.

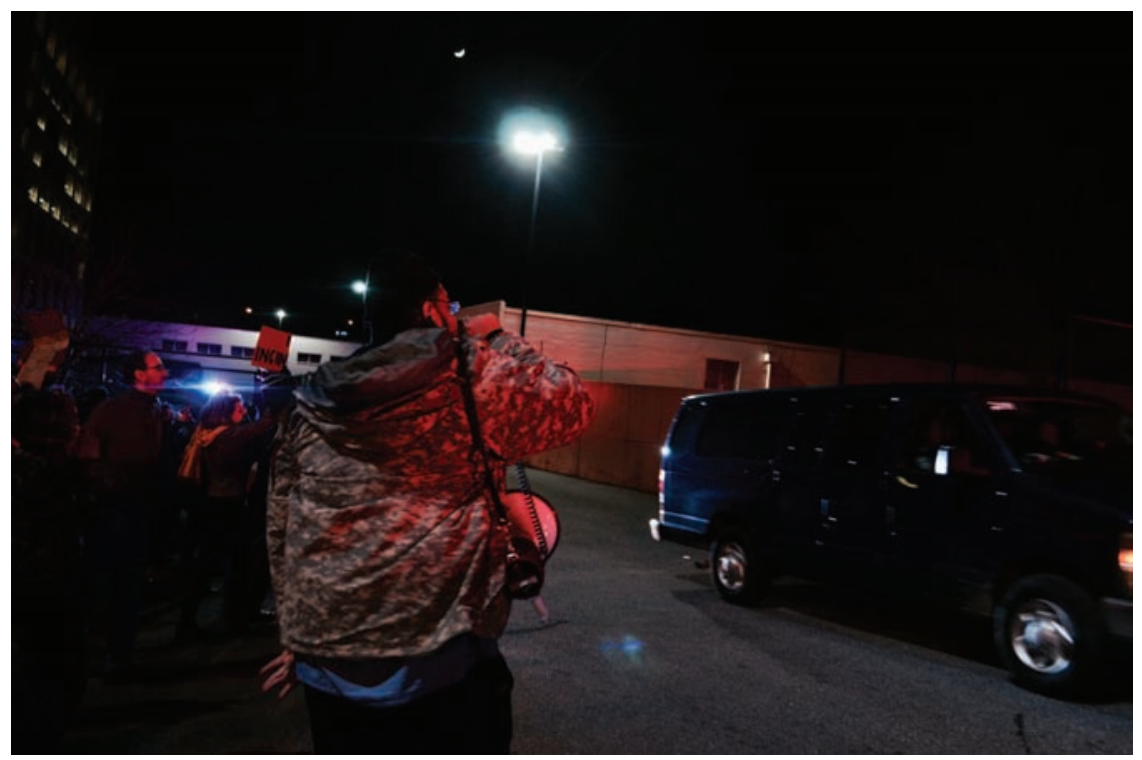

Figure 1. "We can't breathe," December 15, 2015. Photo courtesy of United Workers.

I got to know Elijah and his friends in the back of the van while conducting research on the five generations of environmental degradation that had sparked Curtis Bay's campaign to stop the incinerator. I knew from attending their meetings that the seven arrests, and their subsequent coverage by news media, had been carefully orchestrated to punctuate Curtis Bay's otherwise uneventful encounter with the state. In fact, as I followed the campaign between 2012 and 2016, I documented many efforts by organizers to puncture what they described as a routinized experience of pollution and neglect - to concentrate two hundred years of undifferentiated exposure into crystalized events. What can these efforts tell us about how those in the throes of slow violence rise to the challenge of representing suffering?

Anthropologists have long been concerned with the experience of crisis as a moment of heightened social action, set apart from the "imponderabilia of actual 
life" (Malinowski 1984, 20). But crisis is a privileged designation - a moment of rupture - that incites action and brings contradictions to light (cf. Roitman 2013; Masco 2017). In an attempt to describe scenes that dispossess without ever breaching thresholds of eventfulness, scholars have also begun to attune to sluggish temporalities of suffering. Rob Nixon's (2011) “slow violence," Lauren Berlant's (2011, 95) "slow death," and Elizabeth Povinelli's $(2011,4)$ "quasi-events," for example, depend on forms of delay, deferral, attrition, and accumulation whose ordinariness is their violence. As Nixon $(2011,4)$ explains: "Violence is customarily conceived as an event that is immediate in time, explosive and spectacular in space, and as erupting into instant sensational visibility. We need, I believe, to engage a different kind of violence . . . incremental and accretive, its calamitous repercussions playing out across a range of temporal scales."

Slow forms of violence are not only environmental. In the shift from taking life to letting die, even Michel Foucault (2003) recognized that not all deaths are events. Encompassing chronic health conditions alongside milieus of cruddiness (Povinelli 2011), infirmity (Cazdyn 2012), and ruination (Stoler 2013), slow violence refers to a general wearing out, to "deterioration as a defining condition of . . . historical existence" (Berlant 2011, 95). But it also invokes a particular set of challenges. Neither spectacular nor instantaneous, and often proceeding at a speed that decouples suffering from its original causes, slow violence can be difficult to represent, even to perceive. And though many have acknowledged the consequences of inattention and the anesthetizing effects of routine, fewer have shed light on how people mired in the experience of slow violence themselves use time to maneuver politically.

In this essay, I focus on the deliberate manipulations of time that characterize responses to slow violence and argue that this condition need not incapacitate its victims. Instead, it can invite creative forms of temporal arrangement, orchestration, and a phenomenon I term moral punctuation: an explicit marking of time that condenses protracted suffering and demands an ethical response, eschewing the delays of political caution and the painstaking work of ensuring scientific certainty. My goal, in other words, is not only to draw attention to the insidious nature of slow or invisible suffering but also to emphasize how affected groups occasionally work time to emphasize their vulnerability. Moreover, I focus on the importance of sustained collective action in the adaptation of time as strategy. In doing so, I join others working on the politics of pollution (e.g., Bullard 1990; Checker 2005) while making temporal tactics a more explicit object of ethnographic scrutiny. This focus challenges the impression that time and perceptibility are chiefly 
mechanisms of oppression. Instead-like expertise (Brown 1992; Allen 2003) and access to information (Fortun 2001) - they are overt objects of contestation among historically disenfranchised groups (see also Liboiron 2015).

Like many late-industrial towns, Curtis Bay is an out-of-sight landscape where environmental problems have manifested over decades and where a "tight coupling" (Fortun 2014, 310) between natural, technical, and political systems is felt through bloody noses and stilted breathing. Also known as Maryland's "industrial peninsula," Curtis Bay is a region of multiracial poverty located on Baltimore's southernmost tip, long deemed far enough from the city center for the location of nuisance projects but close enough to provide needed benefits. The neighborhood has managed multiple forms of risk since the nineteenth century, from quarantining lepers during the great wave of immigration to supporting nuclear deterrence with its Cold War chemical arsenal. And these government operations, along with the long-term impact of the petrochemical industry, have left behind significant debris (Stoler 2013). According to the Environment Protection Agency, residents are routinely exposed to elevated levels of fine particulate matter, ground-level ozone, formaldehyde, and benzene. The Environmental Integrity Project puts the region in the ninety-first percentile for pollution-related cancer risk; it also leads the nation in asthma mortality. Recently, the Baltimore City Health Department acknowledged that 50 percent of the deaths in this community are "avertable" (Ames et al. 2011, 10).

In the six years that I have worked in Curtis Bay, I have collected family histories of gastroschisis, a birth defect that causes infants to be born with their intestines on the outside, which the Centers for Disease Control and Prevention have associated with living near hazardous dumps. I have sat with residents on porches, watching as they tally neighbors afflicted with cancer and respiratory disease. Still, as Donna Goldstein and Kira Hall $(2015$, 640) have shown in a different context, "toxic layering" complicates causality, making it easy for regulators to dismiss health inequities as too muddled for consideration and for residents to acclimate to "the banality of toxicity," folding their multiple, ambiguous exposures into an everyday praxis of not noticing. Similar trends populate the literature on factory towns (Walley 2013) and sacrifice zones (Lerner 2012), demonstrating how the effects of gradual industrial incursion discourage state intervention. Slow contamination also strains the attention of the spectacle-driven media. These problems are compounded by the stultifying effects of scientific uncertainty, which obfuscates accountability and can mute the experience of pollution for residents who are confused and fatigued (Auyero and Swistun 2009). 
In Curtis Bay, too, the steady stream of industrial projects and the gradual accumulation of toxics have germinated slowly, complicating work for activists in the community. As one named Greg admitted to me in the weeks leading up to December 15, 2015: "It's exhausting to create an event out of nothing."

Expressions such as this often suggest resignation, but they are not residents' only response to environmental suffering. In Curtis Bay, competing parties have at times been quite deliberate about slowing, speeding up, condensing, and reordering time to serve different needs. Drawing on twenty-four months of fieldwork between 2012 and 2016 - including hundreds of hours of participant-observation, more than ninety interviews, and extensive archival research - this account elaborates three of their temporal strategies. In doing so, it responds to recent calls to theorize speed (Duclos, Sánchez Criado, and Nguyen 2017) and attempts an answer to Elizabeth Povinelli's $(2011,4)$ query about how one might "construct an ethics in relation to . . . dispersed suffering." More importantly, though, it is a provocation to center these investigations on the individuals often depicted as time's casualties. In what follows, I outline the stakes of my argument by situating Curtis Bay within a discussion of time, event, and not noticing. Next, after sketching the slow encroachment of industry and residents' reflections on its routinization, I turn to the campaign against the incinerator and examine three ways that groups have deliberately worked time: by imitating the pace of slow violence (incrementality), ensuring stasis (deferral), and punctuating time through the strategic manufacture of events (concentration). I end with reflections on the pace of climate change and the uprising against police brutality that coincided with the fight against the incinerator, suggesting that in these cases, too, slow violence need not merely impede: it can also invite temporal maneuvering.

\section{OUT OF NOTHING}

In an essay on fallout, Joseph Masco $(2015,153)$ writes that lag - the chasm in time between environmental events and the recognition of their long-term repercussions - is "a major psychosocial achievement of the industrial age." In Curtis Bay, where toxics have accumulated over generations but where old-timers see a net reduction in active industry, lag acts on the sensorium, numbing the impulse to tie this exposure to that disease. Part of the work of mobilizing against slow violence, then, has been teaching residents to recognize past exposures as relevant to the present, and to count minute irregularities in the environment as part of a more expansive toxic atmosphere (Murphy 2006; Shapiro 2015). 
But retraining the senses in the absence of an exposure event has been challenging. By way of comparison, in Bhopal, Chernobyl, and Fukushima, it was the experience of explosion that alerted locals to their toxic vulnerability. There, disasters served as signifying moments, wildly gesticulating that residents should pay attention and bringing multiple spheres of action into momentary synergy. According to Marshall Sahlins (2000, 301), this is the function of events: they "make a difference" by exposing the order of things, rupturing the experience of routine (see also Rabinow 2003). Indeed, there is a wide body of work demonstrating that events condition perception and suggest potentiality, catching people up in the fullness of feeling that something is happening (e.g., Das 2006; Stewart 2007; Lazar 2014). To scholars like William Sewell, Jr. (1996), their ability to transform social practices makes events the very stuff of history.

Of course, not all events make the same kind of difference, nor are different genres of eventfulness equivalent with respect to their social, political, or subjective impact. Instead, as Andrew Abbott (1988) and Robin Wagner-Pacifici (2000) demonstrate, time unfolds on multiple horizons, sometimes bursting in a spectacle of consequence and sometimes fading into normalcy. Take crises: despite the incredible political promise often invested in them, crises are not necessarily transformative. They can change the nature of one's relationship with the state, as Adriana Petryna (2002) and Kim Fortun (2001) have shown in the contexts of Chernobyl and Bhopal, respectively. But they can also reinscribe existing forms of inequality by diverting attention, as Janet Roitman (2013) argues the financial crisis has done and as Naomi Klein (2007) chronicles with respect to what she terms "disaster capitalism." Perhaps because of their political ambiguity, crises have captured ethnographic attention for years, from studies focusing on resource management after catastrophes (Fortun 2001; Petryna 2002; Button 2010) to those exploring cases where crisis has become chronicity (Vigh 2008; Farmer 2011; Adams 2013; Feldman 2016).

But there are many forms of precarity and disorder not captured under the designation of "crisis" that do not command the same critical attention. Consider Nancy Scheper-Hughes's (1992) notion of everyday violence: an existential experience of scarcity, sickness, and death that normalizes suffering. Or consider Javier Auyero and Débora Swistun's (2009, 93) work on toxic ambiguity. Their study of pollution in Argentina depicts a "slow-motion toxic disaster" whose lack of speed effectively dulls the senses to toxicity. Given the resulting sensory aporia, it is not difficult to understand residents' quiescence. Critical responses are perhaps even more challenging to imagine in cases like Christine Walley's (2013) 
study of postindustrial Calumet, all too common in the late-industrial United States: what are people to do when diseases manifest themselves years after factories close- once their ostensible causes have disappeared from the landscape?

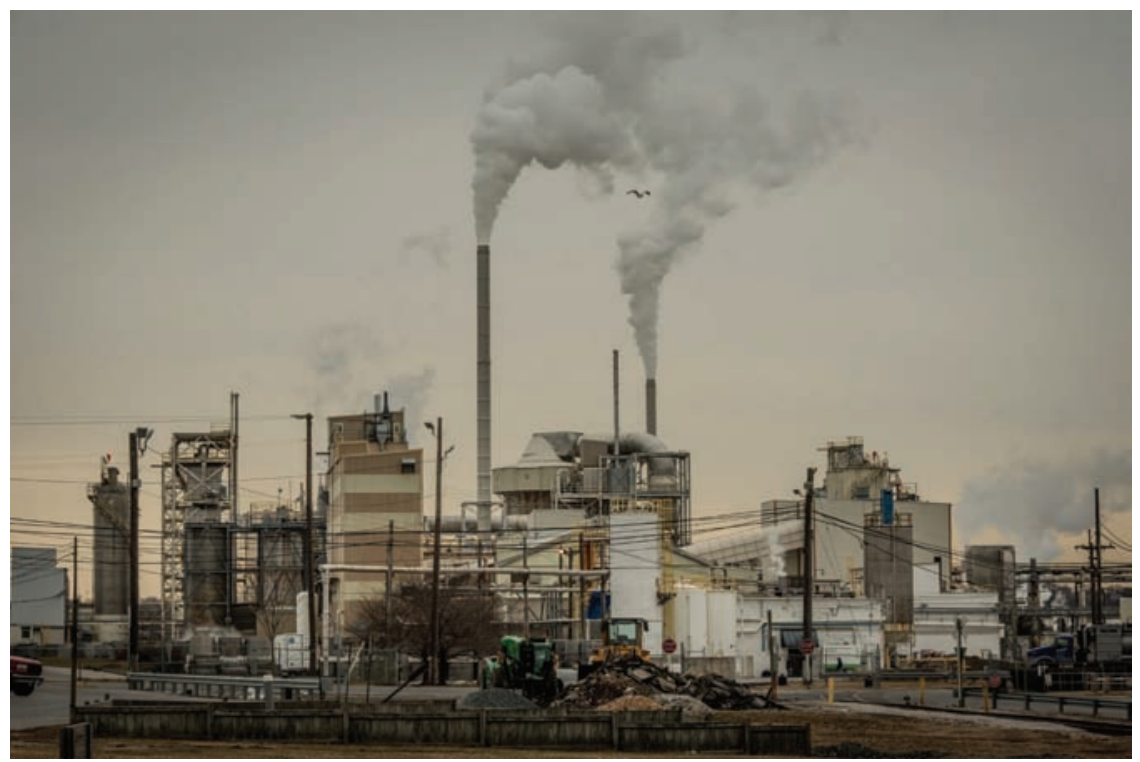

Figure 2. The local skyline, April 2015. Photo courtesy of the Goldman Foundation.

Curtis Bay has much in common with Auyero and Swistun's account, as well as with Walley's depiction of the ties that bind bodies to Chicago's steel industry. Industrial pollution has been a part of south Baltimore for more than a century. Beginning in the 1800s, factories concentrated in Curtis Bay thanks to land-use regulations that pushed nuisances (waste, industry, contagious disease) to the urban periphery. The region soon became home to Maryland's fertilizer, oil, and chemical industries. During the next 150 years, local companies produced increasingly dangerous products (such as asbestos, ammunition, radioactive thorium, PCBs, and DDT), pollution worsened, and plants were joined by massive dumps and military facilities. Elsewhere, I elaborate this history at length (Ahmann, forthcoming). For present purposes, know that life for longtime residents has always revolved around heavy industry. Most have ancestors who came to work in local factories, and even unemployed residents depend on the plant's various efforts at corporate social responsibility: GRACE Chemical funds summer camps for children, CSX hosts an annual Thanksgiving meal, and the neighborhood association would be insolvent without contributions from the local business al- 
liance, featuring partners like Valley Proteins (an animal rendering plant), Abbey Drum (a hazardous waste container manufacturer), and Targa Resources (a natural gas company). Though the composition of plants has changed over the years, as has residents' relationship with industry, locals have long learned to accept pollution as a condition of survival in their community.

For outsiders visiting the region, these entanglements can seem jarring: intersections of Carbon Avenue and Sun Street, Quarantine Road and Efficiency Way, junked car parts, sunflowers, row houses, and oil tanks mark a part of the city that looks like a terrible accident. Rena, a lawyer who in the 1990s represented residents seeking a buyout, described the area as being "like the center of a doughnut. If you had an aerial view, it would look as if an angry god had taken some Monopoly houses and thrown them in the middle of this big industrial ring." Inside, things seem to have happened more gradually. In conversations with older residents, I always ask how industry affected the local environment. "We didn't give it much mind," a white man named Horton once told me. Others have echoed the sentiment: "We never thought about it." "It's always been normal." "I guess I didn't really notice." Things happened in Curtis Bay, but they never added up to happenings. The region's industrial engulfment and its strain on local bodies occurred over such a long time that, in Horton's words, "it hardly seemed worth fretting."

These were the conditions that led Greg, a white organizer in his thirties, to express exhaustion about the prospect of crafting eventfulness "out of nothing." We had been canvassing the blocks of Curtis Bay on a brisk November afternoon, knocking on doors and straining to convince people who had lived amid toxicity their entire lives that, suddenly, they should act on it with urgency. We spoke with young black families who were used to having their health disregarded by the powers that be, and with working-class whites who a decade ago lived comfortable lives, but had since sunken into poverty. The latter group in particular proved difficult to reach: though white residents frequently warmed to Greg and me, many shut their doors when approached by the half-dozen black teenagers who canvassed with the campaign twice a week. Typically, downwardly mobile whites attributed decline to their black and immigrant neighbors, many of whom moved in when factories started closing, and few vested hope in our politicking (Ahmann 2016). After giving our spiel about the proposed incinerator, Greg and I were used to being told that "Curtis Bay's always been a dumping ground," that "it's gotten worse since they moved in," and that our efforts "won't change anything." In the weeks leading up to December 15, 2015, we had spent so many 
days leaving flyers in doorjambs and speaking to ostensibly indifferent people that Greg had a hard time fathoming how the campaign could possibly build a movement out of "nothing."

I knew Greg well and figured that, as a full-time organizer with a degree in social work and experience in the Peace Corps, he did not really mean there was "nothing" people ought to be upset about. The cumulative health effects of industrial pollution, compounded by the threat of one more plant, constituted an indelible something that Greg had shaped his life around. Yet the slow pace of change in south Baltimore did lack the concentration, attention, and drama of contemporaneous crises. (Compare the observation that "Small increments of lead have built up here over years" with the affective appeal, in Flint, Michigan, of "Look! Lead is poisoning our children right now.") Indeed, in our conversations with folks who said they "didn't give [pollution] much mind," I detected a praxis of not noticing that seemed conditioned by the pace of industrial expansion and compounded by scientific uncertainty about the causes of local disease. Mark, whom I met just weeks after he had been diagnosed with cancer, likened the trend to the body's attunement to smell: "Eventually, your nose gets numb to all that. It's kind of like cat litter-after a while you don't smell it, and it's easy to forget you need to change it out."

Certainly residents noticed that there was pollution in their community, and there were occasional reminders that something was amiss - in the way blond hair turned chartreuse when children swam in the cove, in the soot that accumulated on white sheets, in the holes stockings developed when left outside to dry, and in the color snow would sometimes turn ("rainbow," Mark explained, like asphalt tinged with gasoline). But these were ambiguous signs of pollution, and residents often dismissed them as inconclusive, one-off sensings (cf. Shapiro 2015). Given the vague connections between their deteriorating health and these equivocal environmental omens, most have learned to bracket such experiences, cultivating "somatic modes of [in]attention" (Csordas 1993) responsive to their abstruse atmosphere. In her research on the production of political apathy, Nina Eliasoph (1997) shows that this disavowal takes work. But it is a perfectly sensible coping mechanism for residents who feel powerless in the face of risk, who "want not to be worried" (Eliasoph 1997, 619; see also Stawkowski 2016). Even in the part of Curtis Bay where Rena negotiated a buyout, it was not long-term toxicity that moved residents to leave, but the occasional industrial explosion. ("You can't see toxics," Rena observed, "but you can be very agitated about blowing up.") For officials, too, it was an argument about the difficulty of evacuating locals in 
the event of an accident that won the day, not residents' "long dyings" — those "inward, somaticized . . . cellular dramas" so removed from their causes and lacking in spectacle that they remain "unobserved, undiagnosed, and untreated" (Nixon 2011, 6).

\section{WORKING TIME}

Toxic suffering in Curtis Bay would, then, seem to count as a kind of slow violence. But much work remains to be done to understand how those in the throes of this condition diagnose its idiosyncracies and then-beyond enduring them-maneuver, make claims, and transform time into a tool of critique. Indeed, though few working on slow violence reject the notion that its victims can respond, initial elaborations of the concept have been characterized by a general sense of obstruction, even malaise. ${ }^{3}$ For example, Lauren Berlant $(2011,95)$, who examines the attrition conditioned by obesity, portrays agency in the scene of slow death as "maintenance, not making . . . sentience without full intentionality." In this formulation, individuals endure instead of invent, and their debilitation appears overdetermined by conditions that they can sense but presumably not change. Elizabeth Povinelli $(2011,106)$ is slightly more optimistic about endurance, describing it as a "space of potentiality" from which new social projects emerge. Yet such potential often seems to require waiting: one must survive these conditions "long enough . . . to accomplish [the] performative trick" of recognition. And though Rob Nixon $(2011,15)$ argues that writer-activists can tackle the challenge of representing slow violence by "apprehending threats imaginatively that remain imperceptible to the senses," he does less to specify how time itself might be made a medium of resistance or refusal. Without disputing these scholars' observations (on which my own analysis is partially dependent), I offer a different set of tools - tools that, beyond depicting time and perceptibility as mechanisms of social control, also specify how those hamstrung by slow violence work time to alter their conditions. Put differently, I build on work that "critically analyze[s] the politics of temporality and identif[ies] its pernicious effects on certain bodies" (Zeiderman 2016, 164), while also examining how those who experience slow violence choose to participate in such politics. For this, I turn to the campaign against Curtis Bay's incinerator.

The Fairfield Renewable Energy Project was, as one young black campaign leader, Destiny, put it, "a routine development in my community." Proposed by the company Energy Answers in 2009, the billion-dollar project promised to power the Baltimore metropolitan area by burning shredded tires, old cars, and 
municipal solid waste. At the time, Maryland Governor Martin O’Malley was working to reclassify incineration as a Tier 1 renewable-energy source (on par with wind and solar), and several institutions signed contracts with the facility (despite concerns about its safety). In sum, the incinerator was a private enterprise owned by a multinational corporation making claims on a planetary scale, supported by state and federal subsidies, regulated by state, federal, and transnational emissions standards, and set to power local municipalities. As an entity, it tracked the dizzying diversity of interests that had long governed Curtis Bay. And, rather than gesturing toward a vague set of exposures, it materialized the threat of toxicity (see Murphy 2006). This made the incinerator, as Greg once put it, both a "profound illustration" and a tremendous political "opportunity."

In 2012, a diverse group of local high schoolers who participated in an afterschool club with Greg, then a social worker at their school, learned about the proposal from the local news. After researching the risks associated with incineration, learning about area health disparities, and joining forces with United Workers - a Baltimore-based human rights group with organizational ties to the welfare-rights movement - the group officially set out to halt the plant's construction. Their fight has since been featured by dozens of newspapers and attracted alliances with a wide array of organizations, from law firms to environmental institutions. The campaign has also been critiqued by older residents skeptical of left-leaning outsiders and hopeful that the incinerator would reinvigorate industrialism in their community. In short: neither side represents a monolithic group (see Brodkin 2009). As part of the campaign, students have studied their region's history alongside neighborhood seniors, acquired data on toxics with the help of environmental experts, and learned organizing tactics from local labor unions. Together, they have shrewdly portrayed the plant as an imminent risk and an immediate crisis, not because it threatened Curtis Bay with a new sort of problem, but because it unacceptably compounded an old one. Among campaign leaders like Greg and Destiny, there is thus a certain awareness, first, that local history betrays a particularly uneventful form of violence and, second, that temporal appeals can render this history useful.

With a focus on this campaign and in response to questions about techniques that move "quasi-events . . . from potentiality to eventfulness to availability for certain social projects" (Povinelli 2011, 14), I examine three forms of temporal response in Curtis Bay. The first two, incrementality and deferral, are subtle styles that mimic tendencies to accrue or forestall. The third, concentration, challenges slow violence by transforming its representation. In all three cases, 
time appears as the object, not merely the context, of human behavior-it is something people use to direct attention and make claims.

\section{CONSEQUENTIAL MEANTIMES}

Todd and I sat across from one another in one of his neighborhood's several worker-owned cafés. A perpetually disheveled white man and the founder of United Workers, he was recounting the strategy that had marked the campaign's early days. "At first, we thought that the incinerator was going to get built like that," he said, snapping to indicate the anticipated speed of the project. "Six months - so we developed a short-term strategy. . . . But in the meanwhile, we were monitoring the site and we realized that something was wrong: the company wasn't doing anything." I had an opportunity, later, to scroll through several hundred photographs taken during this period. Beginning in 2013, the photos document stasis, featuring the same empty site beyond the same locked gate approximately every week for the following year. In one, weeds sprout out from underneath a vacant blacktop. In another, tangled branches vine themselves across the site's barbed-wire fence. And a series taken that August features six grown geese waddling slowly across the ninety-acre dirt expanse. "For a while," Todd continued, "the whole thing made us feel kind of stupid . . . and it was really draining our energy.”

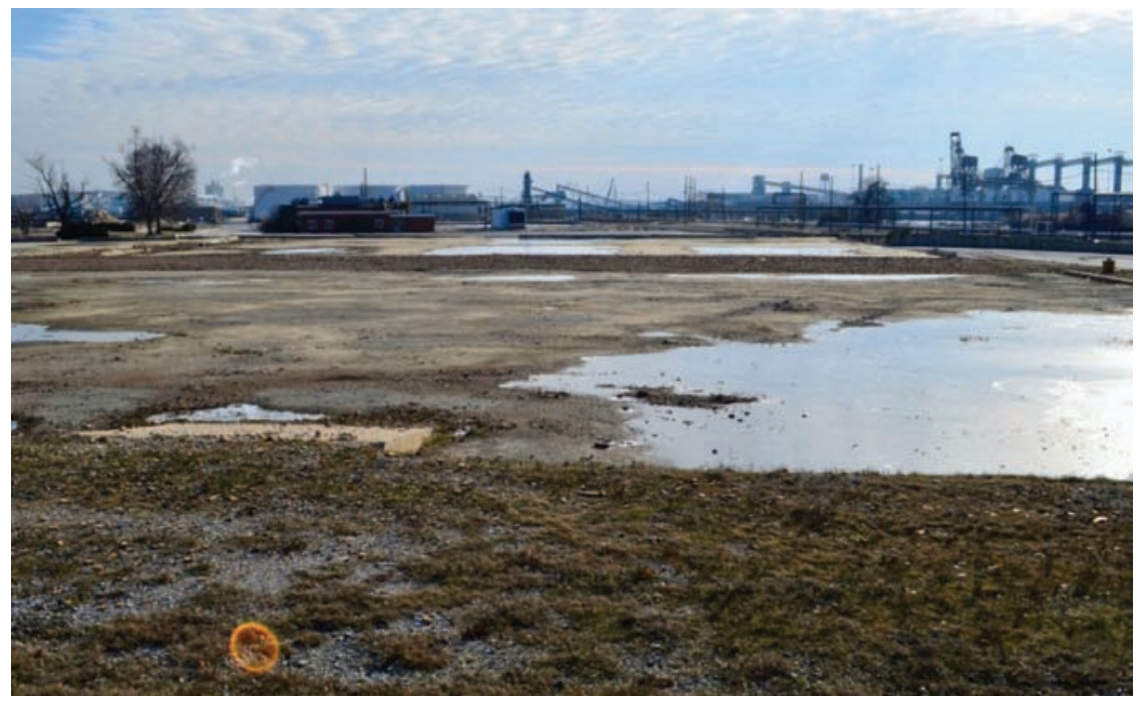

Figure 3. A photo of the still-empty incinerator site, taken during students' routine monitoring. Photo courtesy of United Workers. 
By 2014, Todd explained, activists were finding it difficult to summon a sense of urgency around stopping a development that did not seem to exist. Some neighbors they canvassed assumed the project was dead, and many were flabbergasted to hear that students were fighting over an apparently empty field. As Rob Nixon $(2011,8)$ writes, "delayed effects structure our most consequential forgettings." This went on for some time until, in Todd's words, something "clicked": the incinerator's absence "pointed to a weakness. . . . We had no way of knowing [what], but we did have time to slow down and develop a better strategy."

Todd's comments convey the consequentiality of the meantime, an intervening period between events that tends to lack their definition. Instead, the meantime is murky, open, undefined. It can be rife with possibility or weighted by impatience (Han 2011). Not unlike the pauses intrinsic to industrial production that point to troublesome interruptions in profit and the potentiality of capital ready in waiting (Weszkalnys 2015), the meantime can reward strategies of nonaction, suspension, and procrastination. In my analysis, incrementality and deferral are two temporalities that work within this interim, and which competing parties in Curtis Bay have responded to (as obstructionary or inadequate) and through (to achieve goals without detection or to play up inactivity) in a variety of ways.

Incrementality is a style of response that mirrors the rhythm of slow violence; it describes a gradual buildup that sometimes coalesces into something (an event, a reform, a disease). Toxicologically, incrementality gestures toward the consequences of prolonged exposure not captured in the regulatory sphere, where rules designed to limit the release of a single pollutant from a single plant obscure the biological impact of living for years among heavy industry. Indeed, while many toxics are regulated as though they are benign beneath a given threshold, they tend to linger in the human body and build with the passage of time, accruing in bodies exposed to multiple, continuous releases. And though I do not mean to suggest a direct link between how toxics behave and how toxic developments are resisted, there are striking resonances between slow attrition and incrementality as a political strategy (cf. Pierson 2004, 82; Smith 2015).

Seth, an organizer with one of the country's major environmental organizations, dubbed the tactic "death by a thousand cuts. We'll often lobby for rules that slowly increase the economic burden on polluting industries." Angelo, an air-quality official, also invoked incrementality to describe his work, seeing it as commensurate with "chipping away at a hunk of granite" - an effective (though laborious) process of environmental change-making. Incrementality, then, is a 
pace that stays beneath thresholds of recognition, but that makes something lasting in the process. As a strategy, it can mean weakening an opponent through small, successive victories. It can also mean making progress toward controversial ends while no one is watching.

As we sipped our coffee, Todd explained that the incinerator's construction had proceeded incrementally following its 2010 permitting. Groundbreaking for the project did not even begin until 2013. In the interim, students worked with allies in the environmental sphere to research the plant's prospective customers. They learned that twenty-two public entities had contracted to purchase power from the facility. They also learned that the contracts specified a deadline by which buyers could opt out if the incinerator was not yet providing electricity. With this information in hand, the group pursued a divestment strategy, targeting the institutions one by one and advocating pulling funding. In short, they transformed sluggishness (a perceptual block) into a frame for noticing the project's inadequacies. By April 2015, the campaign had successfully stalled building by removing the project's largest source of financing.

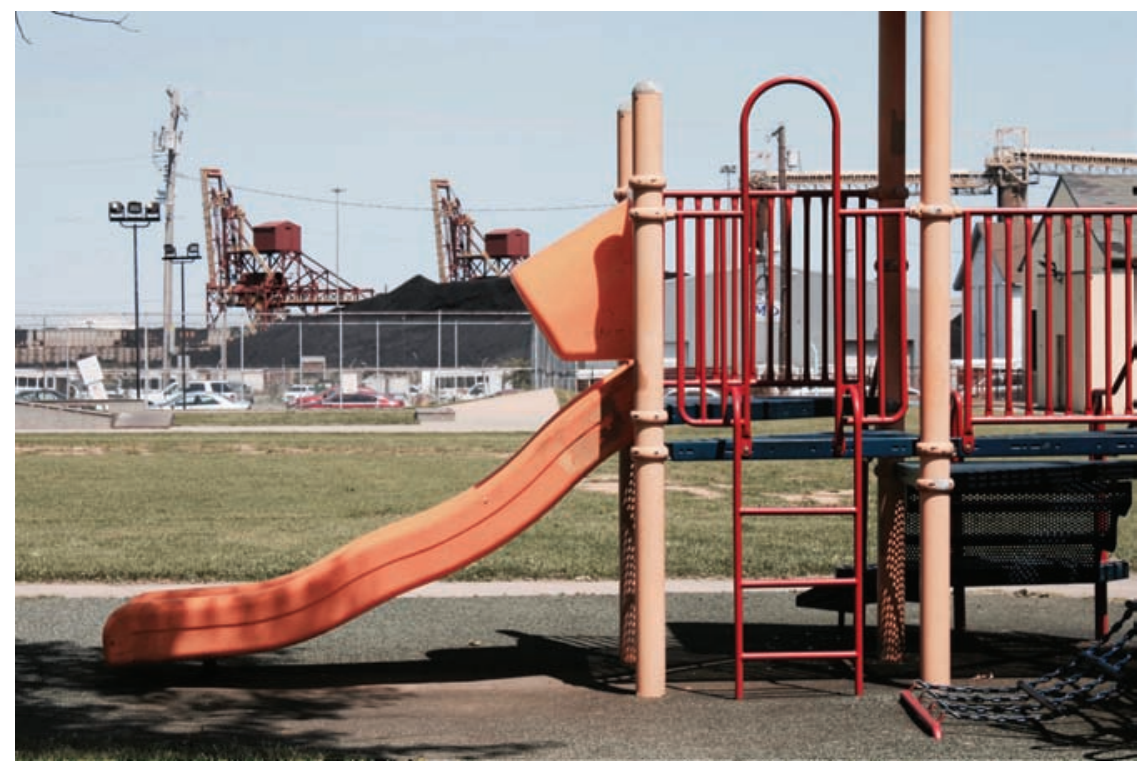

Figure 4. Curtis Bay's backyard, June 2016. Photo by Chloe Ahmann.

Students made a point of emphasizing the resulting stasis on toxic tours they would give visitors to the neighborhood. One sweltering summer afternoon, I walked next to Destiny as she led a group through Curtis Bay, maneuvering past 
coal cars and tanker trucks, stopping at sites that symbolized children's toxic vulnerability, and proceeding to the place where construction was purportedly underway. As we walked, she described how divestment had opened space to pursue another strategy, this one around deadlines embedded within emissions regulations. "Projects like the incinerator hold certificates of public convenience," she narrated, "which means they're supposed to [undertake] 'substantive and continuous construction' within eighteen months," a timeline set by the federal Clean Air Act and typically enforced by the states. She explained that these certificates ensure facilities use the "best available control technology" and satisfy the latest emissions regulations; otherwise, companies could obtain permits to build, retain them for years while requirements grow more stringent and mitigation technology improves, and then construct with cheap, outdated equipment. After granting permits, it is the state's responsibility to monitor construction and ensure that it proceeds "continuously," a pace with legal consequences. And, as Destiny noted, MDE had recorded nearly two years of site visits without any obvious activity.

At this point in the tour, she led groups around a bend in the road to reveal the empty site. To the group's supporters, this emptiness communicated that they had not yet lost the fight. And it dramatized construction delays documented by MDE. One observer even called the term construction a "mockery. . . . It's like if one of us put a shovel in the ground and moved dirt from point A to point B. I guess that's what [the company] was counting." Taken together, these observations kept "the pause prised open" (Weszkalnys 2015, 616), giving shape to the incinerator's shortcomings.

By August 2015, the coalition had begun to capitalize on these lags, pouring energy into catching the company on a technicality. "Pull the permits!" became a rallying cry as students, environmentalists, and social-justice workers mined the minutiae of construction regulation. At public events and at residents' doors, they transitioned from a sermon about health and environmental justice to a script about how construction had been "substantially discontinued for a period of eighteen months or more after it had commenced.” Emboldened by MDE's reports and supported by pro bono attorneys, the campaign implored the agency to recognize that Energy Answers had failed to undertake the "substantive and continuous construction" required by law.

In time, this argument elicited a response from bureaucrats. In November, MDE penned a stern letter to the company, demanding that they prove their permits had not expired. In response, Energy Answers enumerated a short list of 
projects that had unfolded slowly over the years (e.g., drainage system installations, electrical upgrades), almost all of which had taken place underground and out of sight. Essentially, they argued that the project's incremental growth - that happening that proceeds under the cover of stillness and stasis, pacifying resistance through the appearance of absence while accumulating reserves over time- had finally built to a point of consequence. As efforts intensified in anticipation of December 15, 2015, it seemed reports of the incinerator's death had been greatly exaggerated.

If incrementality has been one response to slow violence, a second has more plainly been deferral, or delay. Delay does not build. It stews, halts. One can delay recognition, remediation, and effects. In the environmental sphere, what makes chemical contamination "all the more disturbing," according to one doctor quoted in Rachel Carson's $(1962,188)$ Silent Spring, “is the knowledge that our fate [as a species] could perhaps be sealed twenty or more years before the development of symptoms."

Aside from the immediate effects of events like industrial explosion (such as stinging eyes or rashy skin), most illnesses in Curtis Bay follow a latency period that forestalls intervention and complicates claim-making. Pauline, an elderly resident, found this lag particularly frustrating. In the 1990s, her retired husband was diagnosed with four different cancers that she was certain could be traced to the chemical industry. "But it'd been so long since he'd left the plant," she explained, “we couldn't prove anything.” In cases like Pauline’s, deferral is an engine of slow violence. But with some modification it can also be a tactic- $-\mathrm{a}$ strategic suspension of time or a conservative impulse toward inactivity.

Deferral has marked the Fairfield Project since its inception. Contesting criticism over the three-year delay in commencing construction, a representative from the company argued that the "clock should have stopped" due to a mandatory stop-work order from the state in 2014. But early on, it was Energy Answers that most forcefully complained of delay. Until 2010, the company was embroiled in tense negotiations with the state over having to obtain a refuse-disposal permit. Such a delay "could have been deadly for the project," their attorney then explained. "\$300 million [in stimulus money] is on the line, and we have to get shovels in the ground by the end of the year to qualify" (Mook 2010).

Energy Answers's CEO also complained of delays caused by the campaign. This was his main concern when we met at the empty site to discuss the incinerator. Sitting at a plastic table in a prefabricated trailer - one of the only structures occupying the expanse-he blamed activists for thwarting construction 
through "tactical" requests for additional state review. Specifically, he characterized calls for a health-impact analysis as a "devious means of obstruction," one that concerned investors and cost millions in lost profits. He further reminded me that for every day "the opposition" delayed construction, four thousand tons of trash would go to landfills, which leach methane into the atmosphere and cause our planet to warm, hastening the end of time. "Climate change is a serious problem," he explained, favorably comparing the incinerator's GHG emissions with those tied to landfilling. "Some people will fight anything that isn't perfect. But we don't have time to waste looking for a magical solution.”

References to the "meantime" were another common form of temporal appeal. Activists invoked the phrase to draw attention to things that could have been built on the site (like a solar farm) had the state not delayed invalidating the company's permits. And industry representatives, like the CEO, used it to promote waste-to-energy over more deleterious alternatives. At a tour of Baltimore's existing incinerator in 2016, for instance, one longtime employee told me: "The human race is gradually destroying this planet. We're polluting the ocean, we're polluting the air, we're just ruining our nest." Gesturing toward the two thousand tons of trash churning behind him, I asked if he saw his work contributing to that trend, and he said:

Oh, absolutely! Everything we do harms our environment, but there are things we've got to try. Sometimes I compare the human race to those unfortunate people on the Titanic. . . . Its pumps were taking out twenty thousand gallons of water every minute, but, unfortunately, forty thousand more were flowing in. They bought themselves a bit of time, but the ship of course went down. So that's what we're doing here. We're trying to buy ourselves some time.

Standing in the scorching observation room, I found his statement striking - it was a rare admission of complicity, full of ambivalence about his role in sinking humanity. But I soon noticed that his time reckoning was ordinary: state airquality officials called incineration a "bridge strategy," something they could use to bide the time until wind and solar became more "realistic" options. In all these cases, appeals to the meantime articulated what went on amid deferral as a kind of opportunity cost. But in other cases, delay itself proved advantageous; it was a "weapon of the weak" (Scott 1985) within a labyrinthine regulatory process.

Leah, an attorney aligned with the campaign, spoke openly about taking advantage of every opportunity to legally obstruct the project. In 2012, for in- 
stance, when the company requested an extension on its first construction deadline, it went through an abbreviated agency review that invited public comment. Leah and her colleagues at the Environmental Integrity Project alerted organizers who, in turn, brought dozens to testify against the project. As a result, MDE revised the plant's emission limits, further delaying progress and precipitating another opportunity to intervene when Energy Answers failed to acquire the requisite emissions offsets.

The politics of incrementality and deferral characterized multiple sides of the incinerator debate, with representatives from the company, the agency, and the campaign all seeking to manipulate attention and critique patterns of delay. But protests on December 15, 2015 chiefly targeted delay at the hands of the state. Besides dawdling in its attempts to actualize cumulative impacts legislation, MDE had long deferred its enforcement of project compliance, taking eight months to determine permit validity and letting multiple deadlines pass without consequence. Among themselves, organizers expressed distress over time's asymmetrical politics. At a strategy meeting before December 15, where members of the coalition debated how to get the state's attention, Gwen, a doctor, put her disappointment this way: residents were "still waiting," and the injunction to wait has gone on "month after month after month." In response, Todd slammed his fists down in frustration. "I feel like our opponents own time," he complained. "And when we give in to their timelines, we lose."

\section{MORAL PUNCTUATION}

Another consequence of the project's deferral, however unintended, was that it left room for opposition to swell. One of the tactics campaigners embraced in the meantime was to take control of time, deliberately concentrating it by concocting their own deadlines. While deferral forestalls and incrementality builds at a strategically glacial pace, concentration derives power from its speed. It brings accumulated proceedings to a head and directs them toward a designated moment. William Sewell, Jr. (1996, 843) calls these moments "bursts," explosions of temporal intensity that are more than the sum of their parts; they reframe and often eclipse the gradual changes that precede them. Sometimes, deadlines set by the campaign sought to concentrate months-long struggles into singular events; at other times, they lent immediacy to the incinerator by situating it against Curtis Bay's environmental history.

Early in 2015, for instance, when the group waged an opt-out campaign to get energy buyers to nullify their agreements, activists marked April 25 as a sort 
of judgment day — a day when they would either "celebrate" public institutions for choosing to "do the right thing," or apply tremendous pressure. All twentytwo buyers listened, and by April 25, Energy Answers was forced to face the reality that it had lost its financing. Subsequently, December 15 was to be a deadline for the MDE. After requesting in August that the agency pull the incinerator's permits, following up with hundreds of petitions, and receiving "nothing but silence," the group delivered thirty days' notice to the agency, promising to return with hordes of supporters. "We don't expect [MDE] to respond," Greg said, "which is good-because then the clock starts ticking. They'll delay like they always have and eventually trigger the demonstration where we can highlight why, instead of ignoring us, they should actually do something." In Greg's analysis, quantifying the state's deferral of responsibility and following it with a spectacular call to action would force a response by underscoring MDE's neglect of citizens.

During the years I observed the campaign, I came to think of this strategy as a form of moral punctuation, an explicit marking of time that condensed protracted suffering and demanded an ethical response. Indeed, like punctuation in the grammatical sense, deadlines can be deployed to separate time and clarify meaning; they suggest that waiting has a "narrative escape hatch" (Wagner-Pacifici 2000, 64), a necessary ending. ${ }^{4}$ In Curtis Bay, the incessant assignment of deadlines to a state content to delay was saturated in moral claims - claims that demanded recognition of accumulated wrongs and refused to accommodate delays associated with trudging through the legislative process or epidemiologically proving injuries. We can't breathe, in other words, calls for expediency. It formulates speed as moral when compared with the violence of deferral or the treacherous patience of incrementality. Frustrated with MDE's unwillingness to "do its job" and convinced that "our political levers are broken," organizers thus temporarily set aside a toxicological argument about the incinerator's health impacts and abandoned attempts to debate politicians on official terms. Instead, they decided to draw attention to the state's moral failure with respect to the incinerator - $\mathrm{a}$ failure they argued derived from the state's participation in and refusal to address Curtis Bay's two-hundred-year exposure history.

In this sense, moral punctuation is reminiscent of what Walter Benjamin (1969) calls redemptive time, a recovery of the past that endows it with urgency. In his "Theses on the Philosophy of History," Benjamin (1969, 255) implores historians to "seize hold of a memory as it flashes up in a moment of danger" to put the past to work in contexts of present political need. Benjamin's depiction of the messianic moment as a stop cord halting the progress of a runaway train 
fancies redemptive time, first, as opposed to experiences of protracted suffering and, second, as an emphatic end to accumulated injustices. As I imagine it here, moral punctuation is a less totalizing but similarly creative reconfiguring of history. It seeks to shake up official disregard and recalibrate praxes of not noticingboth embedded in slow violence- - to attune, instead, to an accrual of wrongdoings. ${ }^{5}$ Like the designation crisis, punctuation does work by registering "a moral demand for a difference between the past and future" (Roitman 2013, 9) and insists that history derive meaning from this breach.

In my conversations with Todd, I learned that this strategy drew on decades of accumulated experience within United Workers and its sister organizations. Part of the movement to end poverty, rooted in Martin Luther King, Jr.'s Poor People's Campaign, these groups work (in Todd's words) to “dramatize" situations of protracted harm, from housing insecurity to persistently low wages. In 1968, for instance, the Poor People's Campaign brought thousands to camp out on the National Mall to underscore the costs of poverty in a graphic way. And though the campaign faltered for many reasons — King's assassination among them - this strategy has persisted within the movement for decades. As one example, Todd told me about United Workers' efforts to organize contingent laborers at Baltimore's baseball stadium.

We'd spent years building a narrative. Eventually we put it all at the feet of the [state] and said, "We're done talking." And — crank, crank, crankwe announced a hunger strike. The minute we announced and the media showed, that's what really did it. We'd built up the problem over so many years that when it finally happened . . . they conceded.

One reason the hunger strike was so effective was that it highlighted the paradoxes of a system that expected employees to sell food in exchange for poverty wages. In Todd's words, this is what effective action does: it "puts people into contact with a power system that's otherwise difficult to engage," concentrating its diffuse effects into a single situation. Direct action is, in other words, about more than being disruptive; for Todd, it "makes contradictions plain." To quote King $(1963,768,772)$, it seeks to "foster such a tension that a community which has constantly refused to negotiate is forced to confront the issue. . . . We must come to see," he wrote from a Birmingham jail, "that justice too long delayed is justice denied," and to observe deferral with "moral concern" that transcends mere impatience. 
Students had spent years researching these campaigns. They believed that thoughtfully generating crisis could bring about substantive change. A far cry from what Lauren Berlant $(2011,95)$ describes as "sentience without full intentionality," then, December 15, 2015 marked a studied response to slow violence, informed by years of accrued experience among organizers and designed to cap decades of systemic discrimination. In fact, the desire to stage a concentration of accumulated harms was explicit in the plans for December 15, as Greg explained at a preprotest training:

We'll form a very long line and citizens will proceed into [MDE] one by one. They'll buzz in, enter the office, and say, "I'm here to express my opposition to the incinerator." The idea is that everyone who has been involved will get to follow up directly, but also that their mass will create a backlog for the agency.

Each individual's encounter with the state was on its own to be "utterly ordinary," Greg instructed, but the line's cumulative effects would have symbolic significance and considerable logistical consequences. Besides signifying how individually benign acts can accrue into substantial problems, the crowds gathered on December 15 would show (in Greg's words) that "acts of democratic participation come with an expectation," one the agency had failed to meet for months. "People in Curtis Bay are tired of feeling like their lives are disposable," Destiny explained. "We've got to show them [the state] that there's a price to be paid for ignoring communities."

Leaders carefully mapped their timeline and planned to begin at 4 p.m. Individuals would therefore line up during business hours, but their mass would occupy officials past closing. Meanwhile, organizers would fill the lobby with throngs of protesters. When it began to look like MDE would force citizens out, a small group would join arms, sit down, and refuse to leave until the agency enforced the law. Keeping them on schedule throughout the night would be a designated stage manager, tasked with speeding things up if the line moved too slowly and stalling if it advanced too fast (which would complicate the timing of the sit-in). The sit-in would be the action's primary punctuation, and the media would bear witness.

A few days before December 15, I attended civil-disobedience training in the basement of a church with the activists who had been designated "arrestables." They were black and white, ranged in age from eighteen to seventy, and included students, organizers, a doctor, and a priest. They had signed up, as one activist 
affirmed, to put their "bodies on the line" and to ensure that this confrontation with the state would be theatrical, visceral, and direct. Though ostensibly an opportunity to clarify messaging and practice comporting their bodies to resist (but not provoke) the police, the meeting quickly became consumed with concerns about timing. After role-playing one exchange with law enforcement (in which police arrived on the scene, denied them access to bathrooms, and waited long enough to fatigue the media), we talked at length about the threat of a standoff. What if MDE did not promptly call for help? How long would they wait for officers to respond? Would they risk escalating things to provoke a reaction? Some participants were nervous about a potential confrontation. Elijah, for instance, thought it would be dangerous to get mistaken as a threat to the police. Others felt that there was too much at stake to let the event fizzle out. In one organizer's words: "If this is our chance to confront the state, we should create crisis."

Eventually, despite well-founded nervousness around law enforcement, the group agreed to wait as long as it would take to ensure arrest, forcing state action after many months of neglect. In the process they would orchestrate a "system of correlated antagonisms" (Sahlins 2000, 240) — an event, one expressly designed to highlight the absence of eventfulness. Following the lead of the priest, they would kneel in the face of power and recite lines calculated to moralize Curtis Bay's history of adversity. One student, Josh, described the symbolism of the protest as questioning: "Who's breaking the law here? We're just asking to be recognized by a government that tends to ignore our community." More than a performance of their disdain for MDE, then, December 15 would stage a collision between competing temporal subjectivities (Hall 1980), informed by different values (legal caution, ethical concern), daily routines (media deadlines, office hours), and orientations toward history (that it ought to inform government decisions, that it should be irrelevant to permitting).

December 15 did not go as planned. In anticipation of the protest, MDE had locked its doors, leaving citizens to march outside while officials negotiated with Destiny and a small delegation (unbeknownst to them, the arrestables). Stories that spread later about those who had been locked out for simply trying to deliver a letter, a powerful half-truth, supported protesters' claims that the state had abandoned its responsibility to serve and acknowledge citizens. It was a narrative that even older residents - skeptical of the campaign but deeply disappointed by the government - could identify with. Punctuating time with moral urgency and concentrating Curtis Bay's environmental history within a four-hour 


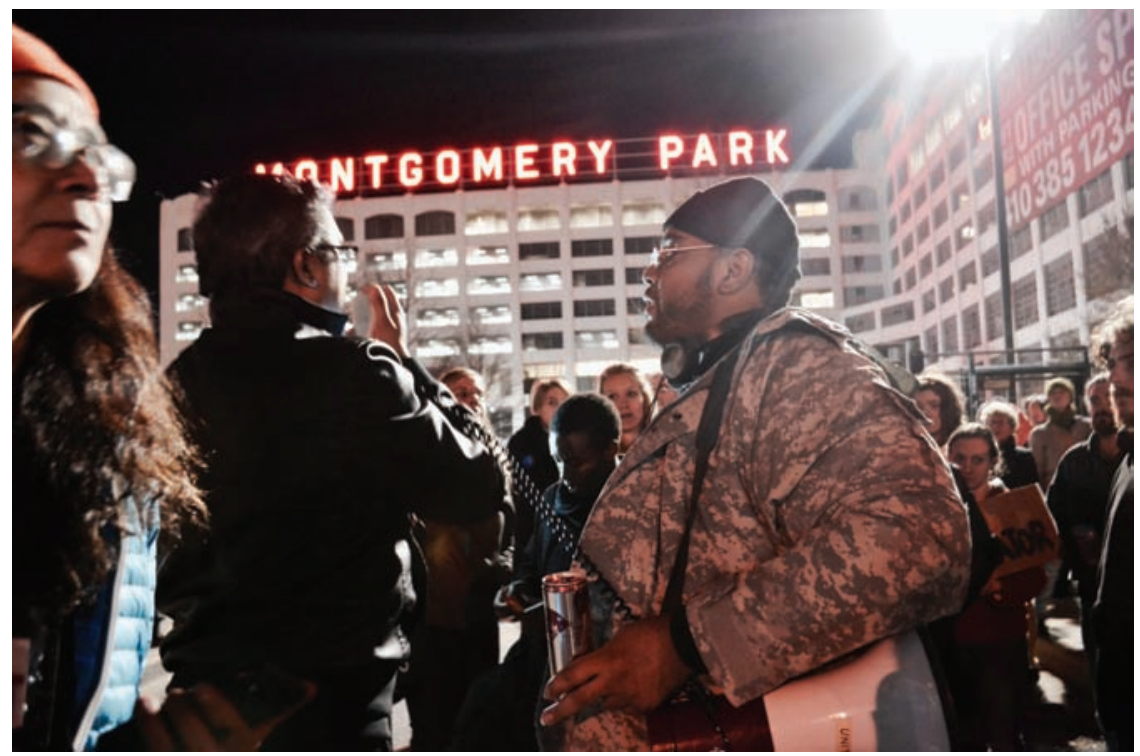

Figure 5. Locked out of MDE on December 15, 2015. Photo courtesy of United Workers.

protest - and through the public images of arrest - the group used these circumstances to fabricate its own crisis. In doing so, it blasted six months of silence from the state while simultaneously bringing years of unrequited protestations and generations of slow, invisible violence into focus. Indeed, in public spaces for days after, locals circulated photos of the event alongside personal experiences of pollution. Even Horton, who had told me that he did not spend time "fretting," was more attentive to his persistent cough and curious whether I had noticed other respiratory problems in his community, and he started to question the wisdom of building another plant in a place "already" overburdened by industrial "abuse." By the following March, organizers had also extracted a response from the state: with little fanfare, MDE determined that the permits had expired, leaving the project to die a slow death while attention shifted to courting projects that promised development without pollution.

\section{CONCLUSION}

Slow violence is a condition that seems to invite incoherence. It takes too long, it is hard to notice, and it casts a wide chasm between effects and the various forces to which we might attribute cause. But it is, in fact, an object primed for interpretive debate, even for new imaginings of accountability. In Baltimore, when faced with the challenge of gradual industrial incursion and its often incon- 
clusive effects on human health, residents subject to the vagaries of delayed destruction learned to work slow violence and its machinery of perceptual confusion. So while it is true that protracted harm can sometimes condition apathy, it can also inspire manipulations of time and creative rearrangements of history.

If anthropology is indeed experiencing a "temporal turn," as Laura Bear (2016, 487) argues, then Curtis Bay suggests that there is much to learn from pivoting from the harsh dimensions of social life embedded in slow violence to temporal forms of resistance, even refusal (see Simpson 2014). It suggests that time and perceptibility can be objects of - not merely obstacles to-political maneuvering. When one pushes past what Sherry Ortner (2016) dubs "dark anthropology" and toward an appreciation for the lively chronopolitics (see Zee 2017) at play in contemporary social movements, time starts to look less like something that happens to people and more like an arena of creative action open to even the most historically disenfranchised groups. Here, I have specified just three strategies of temporal manipulation - incrementality, deferral, and concentration. Broad in scope, they are nonetheless a modest start to what could be a robust vocabulary for thinking time as contested terrain, available for conscious and deliberate use.

It is not my intention, in the process, to overstate the effects of the incinerator victory: Curtis Bay has not suddenly broken the capitalisms invested in industry, nor jolted residents into insurgency, nor disappeared toxic burdens from local bodies. Nevertheless, we might take a cue from Curtis Bay about how people respond to problems "too massive and multiphasic in their distribution of time and space for humans to fully comprehend" (Boyer and Morton 2016) by taking control of temporality. To attend to this behavior is to appreciate how groups grappling with experiences as diverse as exposure (Allen 2003; Checker 2005; Shapiro 2015), erosion (Zee 2017), and illness (Berlant 2011; Cazdyn 2012) might assess time and perception as tools. As anthropologists of the chrono-spastic Anthropocene (see Howe 2016) labor to describe the environmental effects of human activity - effects that are diffuse and at times ambiguous, and which many people gladly go about not noticing — we would do well to attune to cases where people endeavor to halt time, or where they direct attention toward accrual. I imagine there are many contexts, beyond toxicity and climate change, where accrual becomes a case for acting urgently, and where it would behoove scholars to take stock of time as an instrument of social movements.

While I watched the campaign against the incinerator unfold in Baltimore's southernmost neighborhood, similar debates about problems that have gone on 
long enough were happening all across the city. Just days before the campaign's April 2015 opt-out deadline, Freddie Gray, a twenty-five-year-old black man, died from spinal-cord injuries sustained while in police custody. Residents called Gray's death a "breaking point" for Baltimore - a "boiling over," a "tipping point," a "threshold." Overdetermined by generations of manifest police violence against black bodies, residents' initial response did not demand extensive orchestration. As one told a reporter, "Freddie Gray's death made it pop" (Tavernise 2015). But the protests that shook Baltimore in the wake of Gray's death were acts of moral punctuation. They depended in important ways on the accumulation of names - Eric Garner, Michael Brown, Tamir Rice, Walter Scott-whose concentrated deaths at the hands of police helped clarify the meaning of Gray's.

The campaign to stop the incinerator rhetorically absorbed crises like Flint and Freddie Gray to draw attention to less sensational forms of harm in Curtis Bay. Many chanted "no justice, no peace" on December 15, 2015, and campaign statements following the uprising reminded politicians that "the world is watching." While awaiting a response from MDE, Destiny appeared on the radio, warning that "structural injustices have been exposed in this city, and the world will tell the story of how officials in Maryland respond." Such weaving is just one example of how slow violence creates obstacles and opportunities. Nor is it limited to Baltimore; it is a central characteristic of intersectional movements emerging globally.

In Curtis Bay and beyond, the parsing out, the staving off, and the concentration of time have all been responses to slow violence-a problem that implicates how we study, organize, and make policy. Amid all of this, the idea that "it's exhausting to create an event out of nothing" harbors stunning ironies. The prospect that violence unfolding over generations could be imagined as nothing, and the strategic machinations through which groups render it a perceptible something, are both phenomena we ought to train our eyes on.

\begin{abstract}
In recent years, scholars have developed a vocabulary for describing scenes of insecurity, precarity, and disorder too slow to achieve recognition as crises. Concepts such as slow violence, for example, depend on forms of delay, deferral, attrition, and accumulation whose ordinariness exacerbates suffering. But not enough attention has been paid to how those mired in the experience of protracted harm themselves use time to respond to this pernicious condition. In this article, I focus on the deliberate manipulations of time that characterize responses to slow violence by examining a campaign to halt the construction of a trash incinerator in south Baltimore. The incinerator-which
\end{abstract}


posed toxic risk for residents in exchange for the promise of clean, green, renewable energy — was to be the latest in a steady stream of impositions that have plagued local bodies since the nineteenth century. Here, I scrutinize this history and the consequences of gradual industrial incursion on risk perceptibility. I then analyze the ways in which time has been slowed, sped up, reordered, and strategically punctuated by parties on multiple sides of the incinerator campaign. In the process, this article offers up a set of tools that, beyond depicting time as a medium of violence, also specify temporalities of resistance and refusal. Taken together, they suggest that slow violence, rather than merely obstructing response, invites creative forms of temporal orchestration and moral punctuation. [event; perceptibility; risk; social movements; temporality; toxicity; United States]

\section{NOTES}

Acknowledgments This article benefited from readings by Alex Dent, Joel Kuipers, Ilana Feldman, Richard Grinker, Laurence Ralph, Nicholas Shapiro, Savannah Fetterolf, Raquel Machaqueiro, Kimberly Probolus, and Victor Kessler. Special thanks are due to two anonymous reviewers and to the Cultural Anthropology editorial collective- particularly James Faubion - whose insights have indelibly strengthened the ideas in this essay. Research was conducted with the support of fieldwork grants from the National Science Foundation (\#1528490) and the Wenner-Gren Foundation (\#9051). I also owe a great debt to the many archivists who assisted in historical research and to the dozens of residents, activists, bureaucrats, and industrial leaders who graciously shared their experiences with me. Any mistakes are my own.

1. Specifically, the project was permitted to release 240 pounds of mercury, 1,000 pounds of lead, and more than 3,000 pounds of fine particulate matter annually.

2. This phrase references the last words of Eric Garner, who pleaded "I can't breathe" eleven times while a New York City police officer forced him to the ground and restrained him by the neck.

3. This is not a blanket critique. Indeed, environmental justice research has long shown that communities respond to toxic violence creatively (e.g., Bullard 1990; Allen 2003; Checker 2005). I do think, though, that anthropologists have a much more developed vocabulary for describing temporal obstacles to mobilization than for elaborating temporally inflected strategies.

4. While Jane Guyer (2007) and Ilana Feldman (2016) invoke punctuation to describe time that is periodically interrupted, I use the term to describe its intentional parsing out. And though I focus on an explicitly moral type of punctuation, other kinds are certainly possible.

5. In this sense, moral punctuation might be the organizing equivalent of Nicholas Shapiro's $(2015,369)$ chemical sublime, an embodied experience "which elevates minor enfeebling encounters into events that stir ethical consideration."

\section{REFERENCES}

Abbott, Andrew

1988 “Transcending General Linear Reality.” Sociological Theory 6, no. 2: 169-86. https://doi.org/10.2307/202114.

Adams, Vincanne

2013 Markets of Sorrow, Labors of Faith: New Orleans in the Wake of Katrina. Durham, N.C.: Duke University Press. 
Ahmann, Chloe

2016 "Curtis on the Bay: Failed Development and the Mythology of Trump." In "Crisis of Liberalism," Hot Spots series edited by Dominic Boyer, Cultural Anthropology website, November 30. https://culanth.org/fieldsights/993-curtis-on-the-bayfailed-development-and-the-mythology-of-trump.

Forthcoming "Cumulative Effects: Reckoning Risk on Baltimore's Toxic Periphery." $\mathrm{PhD}$ dissertation, George Washington University.

Allen, Barbara L.

2003 Uneasy Alchemy: Citizens and Experts in Louisiana's Chemical Corridor Disputes. Cambridge, Mass.: MIT Press.

Ames, Alisa, Mark Evans, Laura Fox, Adam J. Milam, Ryan J. Petteway, and Regina

Rutledge

2011 "Neighborhood Health Profile: Brooklyn/Curtis Bay/Hawkins Point.” Report for the Baltimore City Health Department. https://health.baltimorecity.gov/ neighborhoods/neighborhood-health-profile-reports.

Auyero, Javier, and Débora Alejandra Swistun

2009 Flammable: Environmental Suffering in an Argentine Shantytown. New York: Oxford University Press.

Bear, Laura

2016 “Time as Technique.” Annual Review of Anthropology 45: 487-502. https://

Benjamin, Walter doi.org/10.1146/annurev-anthro-102313-030159.

1969 “Theses on the Philosophy of History." In Illuminations: Essays and Reflections, edited by Hannah Arendt and translated by Harry Zohn, 253-64. New York: Schocken Books. Originally published in 1940.

Berlant, Lauren

2011 Cruel Optimism. Durham, N.C.: Duke University Press.

Boyer, Dominic, and Timothy Morton

2016 "Hyposubjects." In "Lexicon for an Anthropocene Yet Unseen," Theorizing the Contemporary series edited by Cymene Howe and Anand Pandian, Cultural Anthropology website, January 21. https://culanth.org/fieldsights/798hyposubjects.

Brodkin, Karen

2009 Power Politics: Environmental Activism in South Los Angeles. Piscataway, N.J.: Rutgers University Press.

Brown, Phil

1992 "Popular Epidemiology and Toxic Waste Contamination: Lay and Professional Ways of Knowing." Journal of Health and Social Behavior 33, no. 3: 267-81. http://www.jstor.org/stable/2137356.

Bullard, Robert D.

1990 Dumping in Dixie: Race, Class, and Environmental Quality. Boulder, Colo.: Westview Press.

Button, Gregory

2010 Disaster Culture: Knowledge and Uncertainty in the Wake of Human and Environmental

Carson, Rachel

Catastrophe. Walnut Creek, Calif.: Left Coast Press.

1962 Silent Spring. Boston: Houghton Mifflin.

Cazdyn, Eric

2012 The Already Dead: The New Time of Politics, Culture, and Illness. Durham, N.C.:

Checker, Melissa

Duke University Press.

2005 Polluted Promises: Environmental Racism and the Search for Justice in a Southern Town. New York: New York University Press. 
Csordas, Thomas

1993 “Somatic Modes of Attention.” Cultural Anthropology 8, no. 2: 135-56. https:// doi.org/10.1525/can.1993.8.2.02a00010.

Das, Veena

2006 Life and Words: Violence and the Descent into the Ordinary. Berkeley: University of California Press.

Duclos, Vincent, Tomás Sánchez Criado, and Vinh-Kim Nguyen

2017 "Speed: An Introduction.” Cultural Anthropology 32, no. 1: 1-11. https:// doi.org/10.14506/ca32.1.01.

Eliasoph, Nina

1997 “'Close to Home': The Work of Avoiding Politics.” Theory and Society 26, no. 5: 605-647. http://www.jstor.org/stable/658024.

Farmer, Paul

2011 Haiti after the Earthquake. New York: PublicAffairs.

Feldman, Ilana

2016 "Punctuated Humanitarianism: Palestinian Life Between the Catastrophic and the Cruddy.” International Journal of Middle East Studies 48, no. 2: 372-76. https://

Fortun, Kim doi.org/10.1017/S0020743816000118.

2001 Advocacy after Bhopal: Environmentalism, Disaster, New Global Orders. Chicago: University of Chicago Press.

2014 "From Latour to Late Industrialism." HAU 4, no. 1: 309-329. https://doi.org/ 10.14318/hau4.1.017.

Foucault, Michel

2003 "Society Must Be Defended": Lectures at the Collège de France, 1975-1976. Translated by David Macey. New York: Picador. Originally published in 1997.

Goldstein, Donna M., and Kira Hall

2015 "Mass Hysteria in Le Roy, New York: How Brain Experts Materialized Truth and Outscienced Environmental Inquiry." American Ethnologist 42, no. 2: 64057. https://doi.org/10.1111/amet.12161.

Guyer, Jane I.

2007 "Prophecy and the Near Future: Thoughts on Macroeconomic, Evangelical, and Punctuated Time." American Ethnologist 34, no. 3: 409-421. https://doi.org/ 10.1525/ae.2007.34.3.409.

Hall, John

1980 "The Time of History and the History of Times." History and Theory 19, no. 2: 113-31. https://doi.org/10.2307/2504794.

Han, Clara

2011 “Symptoms of Another Life: Time, Possibility, and Domestic Relations in Chile's Credit Economy." Cultural Anthropology 26, no. 1: 7-32. https://doi.org/ 10.1111/j.1548-1360.2010.01078.x.

Howe, Cymene

2016 "Timely." In "Lexicon for an Anthropocene Yet Unseen," Theorizing the Contemporary series edited by Cymene Howe and Anand Pandian, Cultural

King, Martin Luther, Jr. Anthropology website, January 21. https://culanth.org/fieldsights/800-timely.

1963 "Letter from Birmingham Jail.” Christian Century, June 12.

Klein, Naomi

2007 The Shock Doctrine: The Rise of Disaster Capitalism. New York: Picador.

Lazar, Sian

2014 "Historical Narrative, Mundane Political Time, and Revolutionary Movements: Coexisting Temporalities in the Lived Experience of Social Movements.” Journal of the Royal Anthropological Institute 20, S1: 91-108. https://doi.org/10.1111/ 1467-9655.12095. 
Lerner, Steve

2012 Sacrifice Zones: The Front Lines of Toxic Chemical Exposure in the United States. Cambridge, Mass.: MIT Press.

Liboiron, Max

2015 "Disaster Data, Data Activism: Grassroots Responses to Representations of Superstorm Sandy." In Extreme Weather and Global Media, edited by Julia Leyda and Diane Negra, 144-62. New York: Routledge.

Malinowski, Bronislaw

1984 Argonauts of the Western Pacific. Long Grove, Ill.: Waveland Press. Originally published in 1922 .

Masco, Joseph

2015 “The Age of Fallout." History of the Present 5, no. 2: 137-68. https://doi.org/ 10.5406/historypresent.5.2.0137.

2017 “The Crisis in Crisis." Current Anthropology 58, S15: S65-76. https://doi.org/ $10.1086 / 688695$.

Mook, Ben

2010 “MDE Drops Its Opposition to City Waste Plant." Maryland Daily Record, July 26.

Murphy, Michelle

2006 Sick Building Syndrome and the Problem of Uncertainty: Environmental Politics, Technoscience, and Women Workers. Durham, N.C.: Duke University Press.

Nixon, Rob

2011 Slow Violence and the Environmentalism of the Poor. Cambridge, Mass.: Harvard University Press.

Ortner, Sherry B.

2016 "Dark Anthropology and Its Others: Theory since the Eighties." HAU 6, no. 1: 47-73. https://doi.org/10.14318/hau6.1.004.

Petryna, Adriana

2002 Life Exposed: Biological Citizens After Chernobyl. Princeton, N.J.: Princeton University Press.

Pierson, Paul

2004 Politics in Time: History, Institutions, and Social Analysis. Princeton, N.J.: Princeton University Press.

Povinelli, Elizabeth A.

2011 Economies of Abandonment: Social Belonging and Endurance in Late Liberalism. Durham, N.C.: Duke University Press.

Rabinow, Paul

2003 Anthropos Today: Reflections on Modern Equipment. Princeton, N.J.: Princeton University Press.

Roitman, Janet

2013 Anti-Crisis. Durham, N.C.: Duke University Press.

Sahlins, Marshall

2000 “The Return of the Event, Again.” In Culture in Practice: Selected Essays, 293-352.

New York: Zone Books.

Scheper-Hughes, Nancy

1992 Death Without Weeping: The Violence of Everyday Life in Brazil. Berkeley: University of California Press.

Scott, James C.

1985 Weapons of the Weak: Everyday Forms of Peasant Resistance. New Haven, Conn.: Yale University Press.

Sewell, William H., Jr.

1996 "Historical Events as Transformations of Structures: Inventing Revolution at the Bastille." Theory and Society 25, no. 6: 841-81. https://doi.org/10.1007/ BF00159818. 
Shapiro, Nicholas

2015 "Attuning to the Chemosphere: Domestic Formaldehyde, Bodily Reasoning, and the Chemical Sublime." Cultural Anthropology 30, no. 3: 368-93. https:// doi.org/10.14506/ca30.3.02.

Simpson, Audra

2014 Mohawk Interruptus: Political Life Across the Borders of Settler States. Durham, N.C.: Duke University Press.

Smith, James H.

2015 “'May it never end': Price Wars, Networks, and Temporality in the ' 3 Ts' Mining Trade of the Eastern DR Congo.” HAU 5, no. 1: 1-34. https://doi.org/ 10.14318/hau5.1.002.

Stawkowski, Magdalena E.

2016 “I am a radioactive mutant': Emergent Biological Subjectivities at Kazakhstan's Semipalatinsk Nuclear Test Site.” American Ethnologist 43, no. 1: 144-57.

Stewart, Kathleen https://doi.org/10.1111/amet.12269.

2007 Ordinary Affects. Durham, N.C.: Duke University Press.

Stoler, Ann Laura, ed.

2013 Imperial Debris: On Ruin and Ruination. Durham, N.C.: Duke University Press.

Tavernise, Sabrina

2015 "Health Problems Take Root in a West Baltimore Neighborhood That Is Sick of Neglect.” New York Times, April 29. https://www.nytimes.com/2015/04/30/ us/health-problems-take-root-in-a-west-baltimore-neighborhood-that-is-sick-

Vigh, Henrik of-neglect.html.

2008 "Crisis and Chronicity: Anthropological Perspectives on Continuous Conflict and Decline.” Ethnos 73, no. 1: 5-24. https://doi.org/10.1080/ 00141840801927509.

Wagner-Pacifici, Robin

2000 Theorizing the Standoff: Contingency in Action. New York: Cambridge University Press.

Walley, Christine J.

2013 Exit Zero: Family and Class in Postindustrial Chicago. Chicago: University of Chicago Press.

Weszkalnys, Gisa

2015 "Geology, Potentiality, Speculation: On the Indeterminacy of First Oil." Cultural Zee, Jerry C. Anthropology 30, no. 4: 611-39. https://doi.org/10.14506/ca30.4.08.

2017 "Holding Patterns: Sand and Political Time at China's Desert Shores." Cultural Anthropology 32, no. 2: 215-41. https://doi.org/10.14506/ca32.2.06.

Zeiderman, Austin

2016 Endangered City: The Politics of Security and Risk in Bogotá. Durham, N.C.: Duke University Press. 